\title{
Overview of Energy and Environmental Issues in the Passenger Automobile Industry
}

\author{
Olaleye Michael Amoo' ${ }^{1}$, R. Layi Fagbenle ${ }^{2}$ \\ ${ }^{1}$ Pratt \& Whitney, East Hartford, Connecticut, USA. \\ ${ }^{2}$ Professor of Mechanical Engineering, Obafemi Awolowo University, Ile-Ife, Osun State, Nigeria. \\ E-mail: layifagbenle@gmail.com \\ Received July 10, 2011; revised August 13, 2011; accepted September 2, 2011
}

\begin{abstract}
The global supplies of petroleum are on the decline and the dwindling resource has become increasingly difficult to access. Improved technology is increasingly been required to access petroleum that is in hard to reach geographical environments and has chemical composition that is not entirely compatible with existing processing techniques. Alternative energy involves energy from renewable and non-depleting sources such as wind and solar, offer many opportunities for research and development and are been widely developed globally. These sources of energy are expected to reduce the threat of a changing climate, air pollution and oil dependence caused by the automobile industry. There are many economic, environmental and societal benefits of employing various alternative energy sources or options in the passenger automobile industry for motive power. Transitioning from a monoculture of hydrocarbon-based transportation will be just as signifycant as investments in research and development needed to develop a portfolio of cost-competitive and safe alternative powertrain technologies that can effectively retire the fossil fueled internal combustion engine, without much of any economic stress. In this work, we couple energy and environmental issues to obtain a realistic indication of the future of alternative powertrain technologies for the future of the passenger automobile industry.
\end{abstract}

Keywords: Energy, Alternative Energy, Environment, Efficiency, Automobile Industry, Vehicles

\section{Introduction}

Besides the tens of millions of passenger vehicles that are already in operation today, tens of millions more automobiles and light trucks will be manufactured in the near future to satisfy increasing demand among the growing middles classes of China, Brazil, India and Malaysia as well as other burgeoning economies around the world. At the same time, many experts caution that peak oil has nearly been reached, and some analysts emphasizing that peak oil has already been reached and alternative fuel sources must be identified today to replace the growing demand for current fossil-fuel products. Taken together, these two inexorable forces, growing consumer demand and declining fossil fuel sources, are going to have profound implications for the passenger automobile industry in the years to come. The automobile industry offers a unique environment for innovative technologies for a cleaner environment and to gradually severe ties with the mainstream fossil fueled internal combustion engine. However, the design of future, modern, efficient and ecologically benign vehicles is going to require among other developments, significant improvements in powertrain systems. To determine the current state of technologies and how the passenger automobile industry is using innovations to promote energy-efficient and environmentally friendly solutions and what future trends can be discerned from current events and research directions in the industry, this article provides a general review of the relevant peer-reviewed and scholarly literature, followed by a summary of the research and important findings in the conclusion. The scope of the subject matter in this article is however vast and the length of this review is constrained. Therefore, a mere outline of certain topics within energy and environmental issues as they apply to the automobile industry must suffice including limited citations to provide more depth to the reader. The choice of coverage is admittedly subjective. However, throughout, special attention is given to opportunities for research and development (R \& D). 


\section{Fossil-fuelled Vehicles-Efficiency, Environmental and Economic Issues}

\subsection{Internal Combustion Engines: Piston and Wankel Types-Bsfc (Brake Specific Fuel Consumption), Overall Efficiencies, Environmental Issues}

During the late $19^{\text {th }}$ century, innovations in ICE technologies were providing new opportunities for applying this new source of power in ways that could help move men and materials. By the fin de siecle, the internal combustion engine had become the most promising new technology for providing easier transportation as well as transportation modes such as air flight that would not be possible otherwise [1].

The efficiency of early designs was more important for improved performance than it was for fuel economy [2], but there were some significant developments during this period that would have important implications for future directions in more efficient motor designs and operation [3]. The efficiency of modern ICE is measured in terms of brake specific fuel consumption (BSFC). The fuel economy of the engine is usually expressed as the $\mathrm{BSFC}$, the ratio of the mass of fuel consumed per unit of mechanical work output by the engine shaft. The relative values of the BSFC involve the specific operating conditions to which the engine is exposed. Within the just concluded decade, the most economical (i.e., the minimum) BSFC was about $0.27 \mathrm{~kg} / \mathrm{kWh}$ for gasoline-fueled SI engine, while for diesel-fueled CI engines, it was lower, at about $0.20 \mathrm{~kg} / \mathrm{kWh}$ [4]. Internal combustion engines would also take other turns in evolution that would have implications on BSFC, including the standard piston-driven engine as well as the innovative- but fuel-hungry - rotary engine which are discussed later.

\subsection{Piston}

During the mid- $19^{\text {th }}$ century, a number of so-called free-piston atmospheric were developed based on a principle that was first demonstrated by the Swiss engineer Isaac de Rivaz in 1827 [5]. These early models used a piston that was attached to a long toothed rack which was moved from beneath by the force of gas expansion resulting from burning, a technique that provided movement without restrictions [5]. The partial vacuum that was created during this phase of operation forced the piston to return to its original position and complete the working stroke.

By the turn of the $20^{\text {th }}$ century and beyond, pistondriven ICE were the powertrain of choice in passenger automobiles, all but a handful of the world's one billion motor vehicles produced during the twentieth century were powered by a four-stroke gasoline-burning ICE [6]. The heart of the engine is a piston moving back and forth inside a cylinder in four cycle or 'strokes'. The fourstroke piston cycle operates as follows:

1).On the first stroke (called the "intake stroke" or "suction"), the piston descends, filling the cylinder with a mixture of air and gasoline drawn through an open intake valve;

2).On the second stroke ("compression"), the piston rises as the intake valve is closed, thereby compressing the gasoline/air mixture;

3).On the penultimate stroke ("power"), the piston once again descends, forced down as the gasoline/air mixture is ignited and explodes; and,

4).On the final stroke ("exhaust"), the piston once again rises, pushing the spent gases out the now-open exhaust valve. This four-stroke piston cycle is illustrated in Figure 1.

\subsection{Wankel}

Less common than the piston-driven version, the Wankel engine has nevertheless been used in a few commercial applications. As shown in Figure 2 below, the Wankel engine has a rotor with three points which is geared to a driveshaft.

The rotor rotates in a chamber that is closely fitting and slightly oval-shaped; this configuration creates the right conditions for the power stroke to be applied to each of the rotor's three faces as they are driven past the engine's single spark plug [5]. In some configurations, two or even more rotors are mounted coaxially; however, in these arrangements, power strokes must be timed sequentially. Although the Wankel engine typically weighs about 25

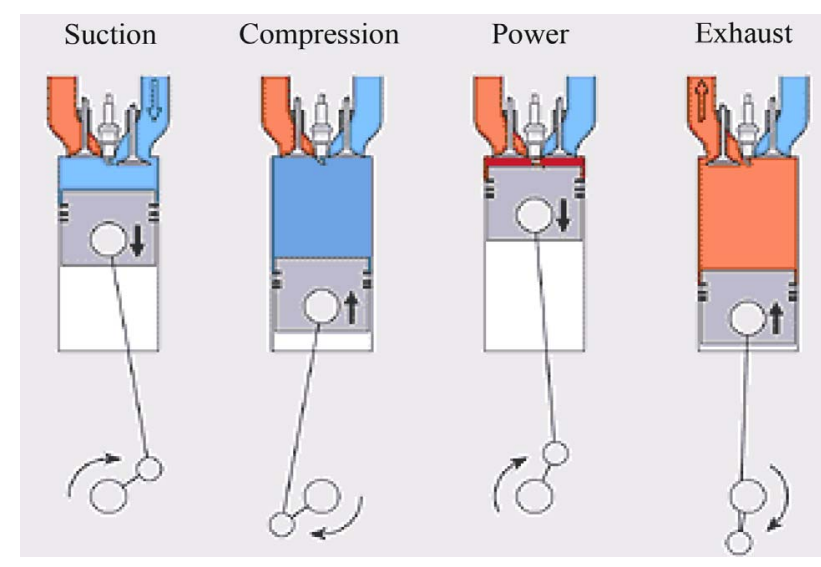

Figure 1. The two-stroke piston engines for motorcycles, small boats and other power applications are similar but complete the above four processes with only two strokes [44]. 


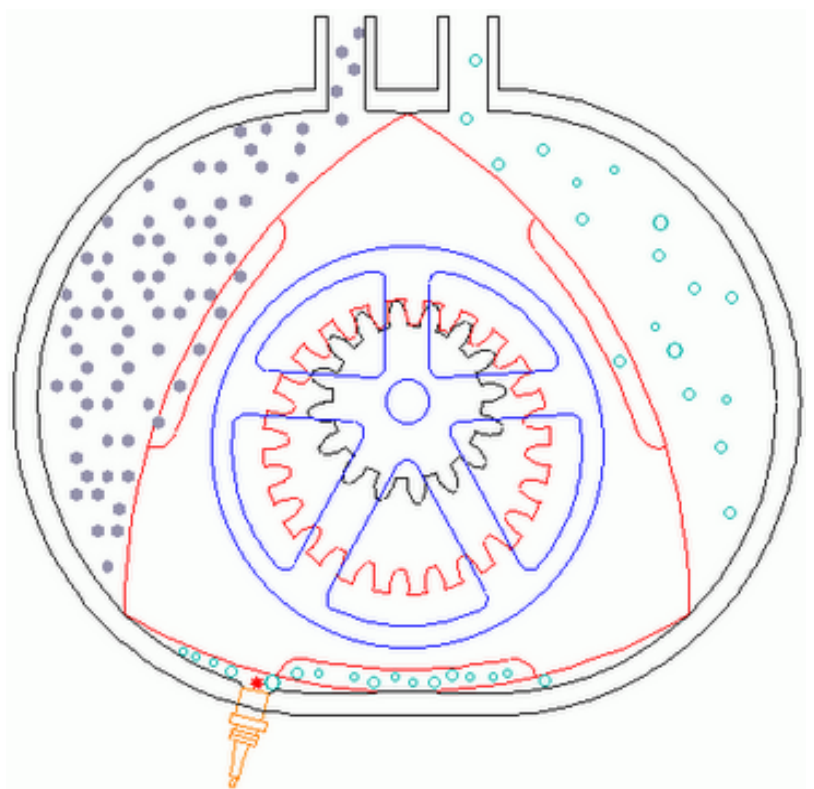

Figure 2. Schematic illustrating rotary engine cycles [45].

percent less than piston-driven engines because it just has two moving parts (i.e., the rotor and the output shaft), fuel consumption levels for these types of rotary engines are high and its exhaust emissions are also relatively high in pollutant content compared to piston-driven engines.

A description of the operation of a rotary engine provided by the Mazda RX7 [7] Association indicates that:

1).A rotary engine works on the compression of income- ing air which is mixed with gasoline at this time.

2).At the peak of compression, the spark plugs fire, igniting the compressed gas and supplying the engine's power.

3). The exhaust leaves the engine and the process is repeated.

4).Due to the design, a rotary engine can generate much more RPMs than a standard piston motor and they are very durable [7].

On average, engine speed for Wankel engines is about 5,500 rpm. The NSU Ro80 was the first production car to use a Wankel engine; however, an open two-seat experimental prototype (the NSU Spyder) preceded this production version. While licenses for the Wankel engine were acquired by Alfa Romeo, Peugeot-Citroën, Daimler-Benz, Rolls-Royce, Toyota, Volkswagen-Audi and others, Japan-based Mazda has been the only contemporary passenger automobile manufacturer to use a Wankel engine with an existing production car. Over the years, research into using Wankel engines for aircraft was conducted and a limited version of a motorcycle using a Wankel engine was produced, but these initiatives failed to generate much interest [5]. According to these researchers, while Wankel became director of his own research establishment at Lindau, on Lake Constance in southern Germany, Mazda continued to improve the rotary engine and by the time of Wankel's death in 1988, the Mazda RX-7 coupé had become a successful, if not high-selling, Wankel-engined sports car.

In all cases, though, improving the respective BSFC rates of both rotary engines and piston engines of various types has become the focus of an increasing amount of R\&D in response to skyrocketing energy costs and increasing consumer demand, particularly from burgeoning economic powerhouses such as China, India, Brazil and Malaysia. Thus, the predominant powertrain remains the gasoline-fueled, spark-ignition four-stroke engine in the vast majority of passenger vehicles today which are more fuel efficient than their two-stroke counterparts and emit less pollutants as well. Balancing this carbon footprint, though, is the fact that two-stroke engine powered vehicles such as motorcycles are lighter and therefore require less total fuel to operate and cost less to manufacture than their four-stroke counterparts in all ranges of passenger vehicles [4].

\subsection{Tyres and Road Friction Issues.}

To put this topic into perspective, as of 1966, expenditure on passenger car tyres was approximately $£ 100 \mathrm{~m}$ (one hundred million British pounds sterling), [8]. In today's monetary terms, such a cost expenditure would be exponentially higher even adjusted for inflation. Anything that detracts from the optimal performance of a vehicle on the roadway will decrease fuel efficiency, and friction of all types has always been the bane of automotive engineers. Despite the challenges that are involved, the numbers of tyres that are involved (about a billion-plus at any given point) mean that even modest improvements in passenger car tyre performance can translate into millions of barrels of oil saved together with the concomitant reductions in greenhouse gas emissions. The performance of tyres is a measure of the coefficient of friction which is the ratio of friction force to normal force to cause sliding expressed as a unitless value (i.e. a measure of the friction force generated between the treads of the rubber tyre and the road surface divided by the load acting on the tyre [9].

At present, automobiles and light trucks provide the majority of passenger transportation and the majority of these types of vehicles use passenger tyres. According to the U.S. Transportation Research Board, most vans, pickup trucks, and sport utility vehicles that are categorized as light trucks by the federal government are considered passenger vehicles [9]. In spite of technological 
innovations that have produced longer-lasting tyres than three decades ago or so, passenger automobile tyres still require replacement every few years as a result of normal wear and tear, and approximately 200 million new tyres are purchased in the United States alone each year [9]. During periods of economic downturn, the replacement of four passenger car tyres can represent a significant investment, and consumers should be aware of several factors in their evaluation of alternatives. In this regard, industry experts emphasize that, the tyres consumers buy will affect not only the handling, traction, ride comfort, and appearance of their vehicles but also fuel economy, which is the average number of miles a vehicle travels per gallon of motor fuel (typically gasoline or diesel fuel). Fuel economy is affected by how efficiently tryes roll across a surface, with the efficiency being a measure of the tyre's ability to conform to the surface while retaining its original shape to the maximum extent possible to reduce mechanical actions that would otherwise be translated into useless heat that requires more fuel to propel the vehicle. Current initiatives to improve the efficiency of passenger vehicle tyres have been more expensive than conventional methods, making progress in this area limited [10].

By combining various designs, material composition and construction features that contribute to improved rolling resistance levels, tyre manufacturers can help increase the fuel efficiencies of passenger vehicles, as well as reduce noise, improve vehicle handling and tyre resistance and appearance in the process. As with any mechanical part, tyres must be adequately maintained with pressure levels being particularly important for performance. Recent innovations in technology have also helped with this aspect of tyre maintenance, and tyre pressure monitoring systems (TPMSs) are now available that can alert operators when a vehicle's tyres become under-inflated. In some configurations, TPMSs employ tyre-mounted sensors to monitor and transmit tyre telemetry data to a receiver; in other cases, wheel-mounted speed sensors are used to identify wheel rotational speeds that can then be correlated with differences in tyre pressure to alert operators to under-inflation. Research efforts must equally continue to quantify effects of various road surface characteristics on tyre wear.

\subsection{Aerodynamics-Styling and Streamlining Is- sues}

Another very important way to reduce friction, improve fuel efficiency and improve performance is to improve the aerodynamics of the vehicle design.

Aerodynamics is a subject matter that deals with two areas which are internal flow similar to that which takes place in a pipe or external flow which takes place around a solid object like a passenger automobile. We are concerned here with the external aerodynamics. The continued increase in fuel prices and regulations on GHG emissions have led to an increase in pressure on automobile manufacturers to enhance current designs of passenger vehicles using minimal changes in their shapes or aerodynamics to reduce drag.

One of the main causes of aerodynamic drag on passenger automobile vehicles is in the separation of flow near the vehicles rear end. There are also two types of drag we are mostly concerned with which are form drag and surface friction drag. Form drag refers to the aerodynamic performance qualities of the vehicle's surfaces with respect to the environment in which it is operated, with form drag being related to the shape of a vehicle's body [11]. Surface friction drag on the other hand is similar to form drag, and this refers to those parts of drag that are represented by the components of the pressures at points on the surface of a vehicle's body that are resolved tangential to the surface [12]. Surface friction is caused by viscous drag in the boundary layer around the object and the drag force $F_{D}$ follows the drag equation, in which $u$ is the velocity of the object whose surface area is $\mathrm{A}$ and which is moving in a fluid of density $\rho$.

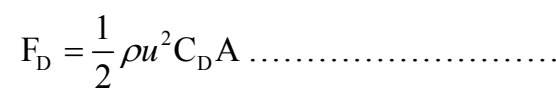

The drag coefficient $C_{D}$ ranges between 0.2 and 0.5 for streamlined passenger vehicles while that of more bluff objects is greater than 1.0 and least bluff is less than 0.1 [13]. Drag can be reduced by shaping the vehicle to be very smooth like an airfoil or a fish, but today's passenger vehicles are obliged to have a body shape that is rather aerodynamically bluff, not an ideal streamline shape as seen on an airfoil or fish. To reduce flow separation mentioned earlier, one well-known example is in the use of dimples, similar to those on gulf balls [14]. Dimples causes a change in the critical Reynolds number (the Reynolds number at which a transition from laminar to turbulent flow begins in the boundary layer). One other method, which is commonly used in the aerospace industry, is in the use of vortex generators (such as rear bumper spoilers or wings) to prevent flow separation. Vortex generators themselves have the tendency to create drag, but they essentially reduce drag by preventing separation downstream of the flow. Whichever method or combination of methods is going to be adopted by the automobile engineering community, to reduce fuel consumption and save energy to protect the global environment, boundary layer control is going to play a signifycant role in future automobile aerodynamics. 


\section{Renewable/Clean Energy based Vehicles-Efficiency, Environmental \& Economic Issues}

\subsection{Solar Photovoltaic (PV) Vehicles (SPV-Vs)}

A purely solar-power powertrain driven vehicle has historically been considered impossible by most automotive engineers. The day may still come when passenger vehicles that resemble current models in size and function are tooling down the highway powered by little more than sunlight, but it would appear that day is still in the future. There however has been an increase in the attention on the integration of solar energy into future passenger vehicles. This integration would work best if coupled to either electric or hybrid architecture. The first model of hybrid vehicle powered by solar panels was launched by Toyota in 2009 demonstrating some level of feasibility for such an idea. A hybrid solar vehicle essentially has many similarities to a HEV for which many studies have been done by many researchers. Many researchers believe, though, that in one form or another, solar energy represents the most promising alternative energy resource across the board, particularly in the long term. It has been remarked by Boaz [15] that, solar-powered vehicles are long overdue and would effect a transformation in cities such as Los Angeles and Mexico City. Price and value are the two main concerns of a SPV-V. The primary value of SPV-V is that it is good for the environment. In addition to avoiding the accumulation of greenhouse gases, increasing reliance on solar energy would wean the world from its reliance on petroleum, world reserves of which will eventually run out. Academic competitions for solar-powered vehicles also take place each year in the United States and interest continues to grow [16]. In 2008, there was a solar car that made the first round the world trip which covered $52,000 \mathrm{~km}$ across 38 countries and ended its journey at the United Nations (UN) climate change talks in Poznan, Poland with the clear message that alternative energy technologies like solar are ecological, economical and can drasticcally reduce emissions of heat-trapping gases. Nevertheless, because of their inherent reliance on the sun and the associated limitations of conventional batteries for energy storage, solar-powered cars remain primarily on the drawing board; by contrast, so-called hybrid passenger vehicles that use two or more different fuel sources (which could include solar power, but more typically biofuels) are becoming increasingly popular as discussed in a later section. Solar photovoltaics in vehicles would need to have a useful life of at least15 years, similar to photovoltaics used in buildings that have a useful life of 20 years or longer, unless they are cheap enough to where they can easily be replaced over time [17]. One aspect where solar energy might contribute more, which offers an opportunity for research and which is rarely mentioned is in the paint being applied to vehicles. Since every vehicle that rolls off the production line is painted, it is only imperative to develop nanobased solar paints that can absorb solar energy which can be used to charge the battery in a solar hybrid electric vehicle or to power other electrical systems in the vehicle. SPV-V will need to generate electricity from the sun using ever part of the vehicle surface. These paints will however be developed to not have any adverse effect on the quality of the paint application process or in later years of vehicle use. In addition, solar can be embedded into the fabric of vehicle seats that will also generate useful amounts of electricity even though it may be behind glass. Tinted glass on vehicles can also contain photovoltaics that have a 15 year life span. These advances in photovoltaic and silicon solar wafer technologies for future vehicles can only be feasible when price of manufacturing has been significantly reduced and are competitive with fossil fuel prices. Solar has already been used in a record breaking 24 hour flight of the all electric solar impulse plane, so the future in terms of automobile applications can only be considered bright and feasible.

\subsection{Biofuelled Vehicles}

Biofuels for transport produced from biomass such as animal and plant waste are attracting considerable attention globally. For the most part till date, biofuels from sugar and starch are the only biofuels that can be supplied in considerable amounts [18]. There are some important factors that must be taken into account when evaluating the relative efficiency of biofuels for passenger vehicle use today. Biofuels have a lower energy density as compared to diesel and petrol but have much higher combustion efficiency than diesel or petrol. On the one hand, because they include a percentage of "renewable" energy resources such as corn-produced ethanol, biofuels can be said to reduce overall demand for fossil fuels and the importance this has for any country's strategic domestic energy needs. On the other hand, though, even the most efficiently produced biofuels require significant amounts of fossil fuels to produce, process, refine, package and transport that may not be included in the overall carbon footprint analysis. It has been remarked by Hayes et al. [19] that, just as world energy prices soared in the summer of 2008, so did grain prices and food prices in general. These market changes increased the attention to biofuel policies and eroded some of the political support that the sector had received. 
Since corn remains the crop of choice in biofuels production especially in the US, increases in its use for biofuel production would invariably lead to increases in the price of corn for food products. Moreover, even in those cases where they produce fewer pollutants than regular gasoline products, the energy required to bring biofuels to market will have a concomitant and cumulative effect on greenhouse gas emission rates as each level in the supply chain contributes its share to the overall total [19] and the land dedicated to biofuel production remains unavailable for other purposes [20]. On balance, biofuels may provide a temporary stopgap measure to help extend current supplies of fossil fuels, but the supporting technologies must be improved to make the end-to-end process more efficient in order for biofuels to become a viable alternative source of fuel for passenger automobiles in the future. In addition, from raw materials to biofuel, the costs of production need to be competitive with petrol and diesel. Costs will drop as many policies, initiatives and standards are designed and deployed to stimulate and support the biofuel industry. Brazil so far represents a model example to the world where bioethanol produced from sugarcane is price competitive and there have been estimates of as much as $90 \%$ GHG savings. [22]. New technological systems often require supportive economic policies [18] and biofuels present such an opportunity for supportive policies as it lowers environmental impacts and GHG emissions when compared to fossil fuels.

\subsection{Natural Gas Vehicles}

Compressed Natural Gas Vehicles (CNGVs) vehicles are among the more promising alternatives to conventional fuel sources that are being explored at present [23]. Natural Gas (NG) which is mostly methane burns more cleanly than conventional fuels like diesel or gasoline and produces $30 \%$ less $\mathrm{CO}_{2}$. Accordingly, $\mathrm{NG}$, unlike other alternative fuels, is capable of simultaneously providing significant economic, developmental, energy security and safety benefits relative to conventional gasoline. As of 2007, there were approximately 114,000 CNG vehicles in the United States and about 3,000 Liquefied Natural Gas Vehicles (LNGVs) [24]. About 66 percent of these NGV's are passenger vehicles (about 1,800 ) versus approximately 240 million conventional (primarily gasoline) passenger vehicles; in addition, just $0.01 \%$ (1,100 of 16.1 million) new passenger vehicles sold in 2007 were NGV's. According to this industry analyst, "For MY 2010, only one NGV was available from an OEM for purchase by consumers - the CNG-fueled Honda Civic GX5 - although there are a number of companies that convert vehicles to CNG before they are sold (usually as fleet vehicles). These technologies, though, will require a significant investment in distribution infrastructure to replace the existing types of fuel pumps that are used with conventional fuel products [25]. For example, existing major fleet operations that rely on $\mathrm{CNG}$ include the U.S. Postal Service, Pepsi-Cola and United Parcel Service, all of which were forced to con- struct their own refueling stations. In fact, about 50 percent of the 800 to 1,000 natural gas refueling stations in the U.S. are currently privately owned or are situated on government sites such as military bases that are not open to the public and many of the CNG refueling stations that are available to the general public require a keycard or other previous financial arrangements with the dispensing company [24]. Though NG is cleaner than coal, gasoline or diesel, it is still a carbon based fossil fuel and its byproducts of combustion are $\mathrm{CO}$ and $\mathrm{CO}_{2}$ which still leads to environmentally damaging GHG emissions. It is even more dangerous for GHG emissions than $\mathrm{CO}_{2}$ so leakage into the atmosphere contributes strongly to GHG emissions. It can also cause severe and damaging explosions.

\subsection{A Comparison of Fossil-Fueled Vehicles and Renewable/Clean Energy Vehicles-Effciency, Environmental and Economic Issues}

While the internal combustion fossil fueled vehicles have improved in efficiencies over the years, it is however difficult to see path to dramatically increasing their efficiencies. Renewable and clean energy vehicles provide much improved efficiencies over conventional ICE vehicles. They also provide a longer driving range or miles per gallon, an important metric to the average consumer, over ICE vehicles especially in a hybrid power drivetrain. Environmentally, while fossil fueled vehicles are also been improved upon to reduce harmful tailpipe emissions, they will still have considerably higher emissions than clean energy vehicles. Electric vehicles for example have zero tailpipe emissions when compared to fossil fueled vehicles. Even though the electricity used to charge batteries in electric vehicles is currently mostly produced from burning fossil fuels, the emissions associated with it from power generation are still lower. While much work still needs to be done to improve clean energy vehicles, they are however better for the environment. The economics of fossil fueled vehicles when compared to clean energy vehicles indicate that clean energy vehicles are cost prohibitive today. Increased adoption and use along with governmental incentives in the short to midterm timeframe will help to bring their costs down and increase affordability. 


\section{Fuel Cell Vehicles (FCVs)-Efficiency, En- vironmental \& Economic Issues}

\subsection{Fuel Cell types, Their Current State-of-The-Art}

A fuel cell is device that converts the chemical energy inherent in a fuel (e.g. natural gas or a clean fuel like hydrogen), along with an oxidant (e.g. oxygen) into electricity, heat and products of reaction. Inside a fuel cell is an electrolyte and electrodes in contact with the electrolyte and it is at this interface that the chemical reaction takes place (Shown in Figure 3).

Hydrogen-fueled fuel cells are compact, quiet, clean and as chemo-electric converters and not Carnotian (Sadi Carnot 1796-1832) heat engines, highly efficient [25]. At first blush, fuel cells would appear to be the answer everyone has been looking for in the alternative energy market. After all, fuel cells helped astronauts reach the moon and return safely, and they have been shown to be efficient in passenger automobile applications. Hydrogen FCV are expected to play a significant role in a hydrogen based economy. Fuel cells, through research efforts continue to show improved performance, durability and cost competitiveness. Larger scale production of fuel cells will most likely commence 5-10 years from now especially by companies such as Ballard based in Canada and
FuelCell Energy Inc. based in Connecticut, USA. Table 1, however shows some features of different types of fuel cells. Proton exchange membrane (PEM) fuel cells so far seem to be better suited for the passenger automobile industry. The efficiency of a fuel cell system is hence defined in terms of the fuel utilization efficiency, number of electrons transferred in the electrochemical reaction, actual cell voltage and the enthalpy of formation as shown in Equation (1).

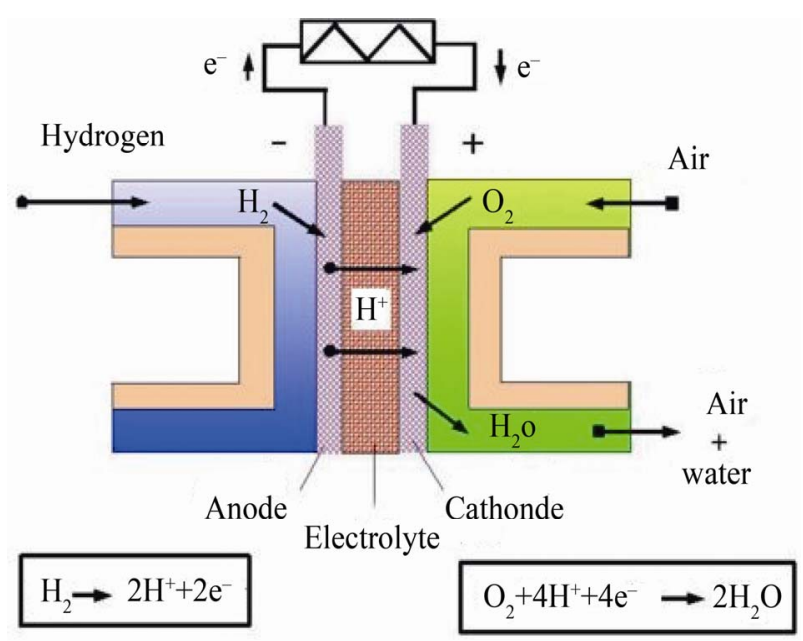

Figure 3. Schematic of a fuel cell.

Table 1. Salient features of several fuel cell types [34].

\begin{tabular}{|c|c|c|c|}
\hline Electrochemistry & Advantages & Disadvantages & $\begin{array}{l}\text { (Anode) Fuel/ } \\
\text { Mobile Ion }\end{array}$ \\
\hline PEMFC & Low temperature operation & $\begin{array}{l}\text { Need for hydration of membrane, low } \\
\text { current densities, acidic nature, catalyst } \\
\text { loading }\end{array}$ & $\mathrm{CH}_{3} \mathrm{OH}, \mathrm{H}_{2} / \mathrm{H}^{+}$ \\
\hline Alkaline (AFC) & $\begin{array}{l}\text { Mature technology, low temperature } \\
\text { operation, high power density }\end{array}$ & $\begin{array}{l}\text { Electrolyte corrosivity, fuel free of trace } \\
\mathrm{CO}_{2} \text { to avoid carbonate formation }\end{array}$ & $\mathrm{H}_{2} / \mathrm{OH}^{+}$ \\
\hline $\begin{array}{l}\text { Direct Methanol } \\
\text { (DMFC)-Proton exchange }\end{array}$ & $\begin{array}{l}\text { Low temperature operation, allows } \\
\text { direct introduction of hydrocarbon fuel } \\
\text { to stack }\end{array}$ & $\begin{array}{l}\text { Low power, several competing mechanisms, } \\
\text { slow cathode methanol oxidation reaction }\end{array}$ & $\mathrm{CH}_{3} \mathrm{OH} / \mathrm{H}^{+}$ \\
\hline $\begin{array}{l}\text { Direct Methanol } \\
\text { (DMFC)-Alkaline }\end{array}$ & $\begin{array}{l}\text { Low temperature operation, allows } \\
\text { direct introduction of hydrocarbon fuel } \\
\text { to stack }\end{array}$ & $\begin{array}{l}\text { Carbonate formation resulting in loss of } \\
\text { alkalinity limiting its life time }\end{array}$ & $\mathrm{CH}_{3} \mathrm{OH} / \mathrm{H}^{+}$ \\
\hline Phosphoric Acid (PAFC) & $\begin{array}{l}\text { Mature technology, demonstrated } \\
\text { uninterrupted operation for long period } \\
\text { (1 year) }\end{array}$ & $\begin{array}{l}\text { Electrolyte corrosivity, complex system if } \\
\text { hydrogen is generated from methane ref- } \\
\text { ormation }\end{array}$ & $\mathrm{H}_{2} / \mathrm{H}^{+}$ \\
\hline Solid Oxide (SOFC) & $\begin{array}{l}\text { High reaction rates, low precious } \\
\text { metal catalyst requirement, direct } \\
\text { introduction of methane into fuel cell } \\
\text { for 'internal reformation' }\end{array}$ & $\begin{array}{l}\text { Complex sub-systems (air and fuel pre-heat- } \\
\text { ers, and complex cooling systems)- resulting }\end{array}$ & $\mathrm{H}_{2}, \mathrm{CO} / \mathrm{O}^{2-}$ \\
\hline Molten Carbonate (MCFC) & $\begin{array}{l}\text { Direct introduction of methane or coal } \\
\text { gas into fuel cell }\end{array}$ & Electrolyte corrosivity & $\mathrm{H}_{2}, \mathrm{CO}$ or $\mathrm{HC} / \mathrm{CO}_{3}{ }^{2-}$ \\
\hline
\end{tabular}




$$
\eta=\frac{\text { electrical energy produced }}{\text { enthalpy change in fuel oxidation }}=\frac{\Delta \bar{g}_{f}}{\Delta \bar{h}_{f}}
$$

Where $\bar{g}_{f}$ is the Gibbs free energy change of reaction expressed per unit mole of the reactant or product and $\bar{h}_{f}$ is the enthalpy change for a 'combustion' reaction in a fuel cell. Accordingly, every fuel cell vehicle is also an electric vehicle. The electric traction system works silently and at high efficiencies. The electric engine provides smooth acceleration with high torque and allows for less gear shifting than ICE. Electric vehicles may be designed with two gearshift instead of modern, but expensive, six gearshift boxes. Moreover, fuel cells are environmentally benign because they are not burdened by the need to process toxic exhaust emissions because the gas preparation has already taken place prior to the entry of the fuel into the fuel cell. Despite these attributes, the majority of fuel cells require pure hydrogen for their operation to alleviate problems of impurities such as catalyst poisoning and membrane failure making fuel storage considerations a major obstacle to the deployment of this technology. Nonetheless, hydrogen being the lightest element in the periodic table of elements is also the most abundant element in our universe. Although hydrogen is a secondary form of energy, it can be produced from any primary energy source such as oil, coal, natural gas, nuclear (as a source of electricity for electrolysis of $\mathrm{H}_{2} \mathrm{O}$ ), and from several renewable energies. Hydrogen is energy of the future. It's environmenttally and climatically benign. It will effectively decarbonize our fossil based energy system and will guarantee clean transportation through EV that will have no range limit. Hydrogen energy is Kyoto compatible [25]. It so far remains the last missing addition to a continuously developing energy mix [26]. Since hydrogen is energy that exists everywhere, there can be no monopoly, market speculation, manipulation or a hydrogen cartel in the frame of OPEC.

Hydrogen does not occur as pure hydrogen on planet earth. It occurs bound with oxygen in the form of water or bound with carbon in a range of hydrocarbons. To separate hydrogen from water, electrolysis is the widely established method which electrically separates water into its components of hydrogen and oxygen as shown in Equation.3.

$$
\mathrm{H}_{2} \mathrm{O}+\text { Energy } \rightarrow \mathrm{H}_{2}+\frac{1}{2} \mathrm{O}_{2}
$$

Other methods of producing $\mathrm{H}_{2}$ are briefly discussed in Table 2.

Table 2. Production methods for hydrogen.

Production Methods

PhotoElectrolysis

Biomass Gasification

Coal Gasification

Steam Methane Reforming (SMR)
Brief Description and Status

Uses sunlight to split water using a photoelectrode or a semi-conducting material. Incoming light produces enough voltage to split water into its constituent gases. Still in its early stage of development.

This is achieved by extracting $\mathrm{H}_{2}$ from $\mathrm{H}_{2}$-rich biomass like wood chips and agric waste by heating in a controlled atmosphere. Its main hurdle has been more economic than technical and increasing demand for $\mathrm{H}_{2}$ will make the production process economically viable.

$\mathrm{H}_{2}$ is produced from coal by reaction with steam. While this produces $\mathrm{H}_{2}$, coal mining is damaging to the landscape and burning coal produces harmful GHG emissions. However techniques are been developed to sequester the harmful emissions such as $\mathrm{CO}_{2}$.

Virtually all $\mathrm{H}_{2}$ produced worldwide comes from natural gas reforming which is done in a two-step process producing $\mathrm{H}_{2}$ and $\mathrm{CO}_{2}$. These steps are $\mathrm{CH}_{4}+\mathrm{H}_{2} \mathrm{O} \leftrightarrow 3 \mathrm{H}_{2}+\mathrm{CO}$ and $\mathrm{CO}+\mathrm{H}_{2} \mathrm{O} \leftrightarrow \mathrm{H}_{2}+\mathrm{CO}_{2}$ This production process is relatively inexpensive and efficient producing moderate $\mathrm{CO}_{2}$ emissions. Sequestration of harmful $\mathrm{CO}_{2}$ will also be required for this process. It is a commercially available production method and widely used with a reforming efficiency of $65 \%$ to $75 \%$. 
The high pressures needed for compressed hydrogen tanks storage (typically between 5,000 and 10,000 psi) used for refueling and operating fuel cell vehicles do require carbon fiber and aluminum liner coatings to accommodate the design requirements. These high pressure levels are necessary, though, in order to achieve performance comparable to gasoline-powered engines. Like gasoline, hydrogen can be dangerous in the event of accidents [27]; in response, some fuel cell vehicle prototypes feature metal hydride storage systems that are designed to accommodate the high weight and low stored energy-to-weight ratios as well as the energy input levels that are required for hydrogen tank operation. There is also ongoing research underway to find ways to store hydrogen in nanofibers, with some scientists maintaining that it might be possible to produce vehicle ranges up to several thousand kilometers per tank filling.

At present, the majority of fuel cell vehicles employ a compressed hydrogen design. Despite obstacles in the Wheel of progress, these obstacles are been dismantled through research by creative solutions and technological advancements and progress, however small, is been achieved. Reduction in the cost and weight of fuel cells will provide for significant improvement and should gradually lead to a more increased adoption or integration of fuel cells. With increased number of FCV being manufactured, issues of a lack of infrastructure for refueling should also begin to see an increased ramp up where by the consumer and general public can easily pull into a hydrogen fuel station, fill up and drive off. While hydrogen storage and safety issues still need to be thoroughly addressed especially for motive power applications, water and thermal management issues equally still need to be addressed for fuel cells.

\subsection{Likely Future Development Paths}

In the short-term, the transition to alternative energy vehicles will likely involve several types of hybrid vehicles (HVs) that are capable of using renewable energy sources while still possessing the ability to run on an internal combustion engine as a backup [28]. Hybrid electric vehicles (HEVs) will probably emerge in the short-term as a major compromise between all-or-nothing approaches. HEVs combine an electric motor and battery pack with an internal combustion engine to improve efficiency. Some versions of HEVs recharge batteries while the vehicle is being operated, thereby reducing reliance on external chargers; in other versions of HEVs, charging after use by plugging them in is required, but in either case, [23] emphasizes that, range and performance can be signifycantly improved over electric vehicles. Ultimately, then, one or a few alternative energy methods will emerge as frontrunner in this quest for viable replacements for fos- sil fuels, including the use of electric vehicles which are discussed further below.

\section{Electric Vehicles (EVs) and Electric Vehicle Battery Charging Systems-Efficiency, Environmental and Economic Issues.}

Some of the major obstacles to the introduction and use of EV today are the limitations of the conventional batteries that are used to store the energy needed to power them and the economic and environmental issues that are associated with their deployment, and these issues are discussed. Continued technological advances in the automobile industry have placed a renewed and ever increaseing pressure on battery manufacturers and OEM battery providers to meet design challenges of improving fuel efficiency while meeting the demands of power hungry electrical applications.

\subsection{Charging and Discharge Efficiencies of The Main Electric Vehicle (EV) Battery Types}

With traditional gasoline products, consumers simply pull up to the pump, fuel their vehicles and go. Although in the U.S. consumers are required to pay inordinately high prices for the privilege, the refueling process is typically fast and convenient. In very sharp contrast, the batteries used in most electric vehicles at present require relatively lengthy recharging times compared to the amount of travel that each recharging can provide [20,21]. Ref [30] identifies some key requirements for future automotive batteries. The existing charging efficiencies of EV batteries must be improved to reduce recharging time, and innovations are also needed to help produce the same type of operating efficiencies with EV batteries that consumers are accustomed to with their gasoline-powered ICE. Battery cell architectures or assembly still needs to be explored in such a way that increases power output, reduce weight and without any detrimental effect to battery performance such as thermal runaway. There is also a role for automobile electronics themselves to play in the efficiency of automotive batteries of the future [31]. Remarkably, whilst energy and power densities of automobile batteries have increased progressively, and weight, volume and cost have continued to decrease, these areas still represent an area of opportunity for R\&D.

\subsection{Economic and Environmental Issues}

As with biofuels and fuel cells, there are some significant economic and environmental issues associated with the batteries used to power electric vehicles. New technoloes may solve certain problems but they may also intro- 
ce new ones. EV batteries could also cause an additional waste disposal problem. Nevertheless, Battery Electric Vehicles (BEVs) can provide enormous fuel savings for consumers. For instance, the results of a 2007 study conducted by the EPRI estimated the costs of operating a plug-in hybrid electric vehicle would cost the equivalent of about 75 cents per gallon of gasoline [20]. In an era of $\$ 4.00$-plus a gallon gasoline (U.S. price), this cost effiency would appear to be highly attractive irrespective of the other constraints involved; however, the 75 cents per gallon estimate was calculated by using a wide range of variables, significant changes in any of which could eas$\mathrm{y}$ increase the costs of electricity. Some estimates also indicate that the use of plug-in type electric cars could save the equivalent of about half of current U.S. oil imrts and a study by the U.S. Department of Energy's Pafic Northwest National Laboratory showed that existing electricity generating resources could provide the energy needs for 75 percent of America's current fleet of pasnger vehicles without the need for any new power-enating plants. Replacing this 75 percent of passenger vecles would save approximately 6.5 billion barrels of oil each day, representing about 52 percent of the country's current oil imports [20]. The environmental impact of recharging electric vehicles is also less than gasolineowered counterparts, with a follow-up study by the nonofit EPRI in 2007 estimated that it might be possible to reduce greenhouse gas emissions by as much as 10.3 billon metric tons by 2050 in a high PHEV penetration scenario. Moreover, there are signs that solar-and-windowered electricity generation will become increasingly available in the future, providing an even cleaner source for recharging such a national fleet.

In order to gain the maximum return on any investment in alternative energy resources for environmentally sustainable purposes, though, it may be necessary to incorporate other initiatives into a broad-based, comprehensive approach. For instance, an environmental sustainability initiative at a resort in California included: (a) using renewable energy and renewable energy vehicles; (b) use of lake water, (c) ecological food products and long-lasting inventory items; (d) use of fewer chemicals; (e) limiting air and water pollution; and sorting waste to reduce the weight of waste per guest; and (f) ensuring that waste is handled properly by local authorities [31].

\section{Possible Limits to Efficiency \& Environmental Gains and Benefits From Current R\&D Effort.}

One of the potential limits to any environmental gains realized through current $R \& D$ projects is the increased demand for inexpensive and efficient passenger vehicles that will create a corresponding increase in the amount of overall energy needed to manufacture and power these increasing numbers of vehicles particularly in the developing countries with rapidly expanding middle classes. In this regard, there is the possibility that, the availability of cheap and very economical vehicles may trigger a demand response in the form of increased vehicle-mileage. In this case of PHEVs, though, the environmental impact of this increased demand would be far less than with gasoline-powered vehicles and the increased commerce and quality of life issues that would result appear to make this a less relevant factor for many developing nations today.

\section{Impact on Developing Countries of Africa}

\subsection{Market Share in Each of the Above Categories}

Internal combustion based engine technology has radicalized African economies. It determines Africa in more ways than just motive power alone. Life in many cities in Africa would be less comfortable without water pumps, which are mostly powered by hand while many others are powered by the ICE, solar power or grid electricity. Life would equally be less comfortable without ICEdriven electricity generators and motorized transportation. The emissions with attendant poor air quality from these ICE-technologies is however becoming of national concern in a large number of countries on the African content, where anthropogenic emissions of combustion particles have considerably increased [33].

The respective market shares of alternative fuel passenger vehicles for the countries of Africa will likely be a function of individual consumer purchasing power, gross domestic product and availability. While availability will depend on individual countries' political and commercial will to bring alternative fuel vehicles to their markets, the respective economic indicators of the top-ten African nations in terms of their gross national per capita income is more readily discernible as shown in Table 3. Figure 3 is however a graphical breakdown of Table 3 for the top 5 African nations.

While all of these leading African nations are on track to gain increased access to their official development assistance (ODA) from he international community in the future, the top five appear to be most well poised to support an alternative energy vehicle initiative and these top five countries are illustrated graphically in Figure 3 below.

As can be seen from Table 3 and Figure $\mathbf{4}$ above, of the five leading African countries in terms of personal income, Botswana, Gabon and South Africa appear to represent the most viable markets in the near term for alternative fuel vehicles and the respective market shares for each type of 
hybrid based on their higher per person income levels. South Africa, though, does appear to enjoy a competitive advantage based on the country's experience in the automobile manufacturing industry. As can be seen from Figure 5, where the x-axis indicates years from 1980 to 2003 and the $y$-axis indicates number of vehicles produced, South Africa has experienced modest but consistent increases in its automobile manufacturing capacity.

Table 3. Gross national per capita income: Top-Ten African countries (as of year-end 2010) [46].

\begin{tabular}{ccc}
\hline World Rank (out of 170) & Country & Gross National Income Per Person \\
\hline 64 & Botswana & $\$ 3,201.68$ \\
66 & Gabon & $\$ 2,861.97$ \\
68 & South Africa & $\$ 2,751.22$ \\
74 & Tunisia & $\$ 1,983.58$ \\
85 & Namibia & $\$ 1,728.70$ \\
93 & Tonga & $\$ 1,371.78$ \\
96 & Swaziland & $\$ 1,219.70$ \\
119 & Djibouti & $\$ 1,199.84$ \\
120 & Cote d'Ivoire & $\$ 593.05$ \\
\hline
\end{tabular}

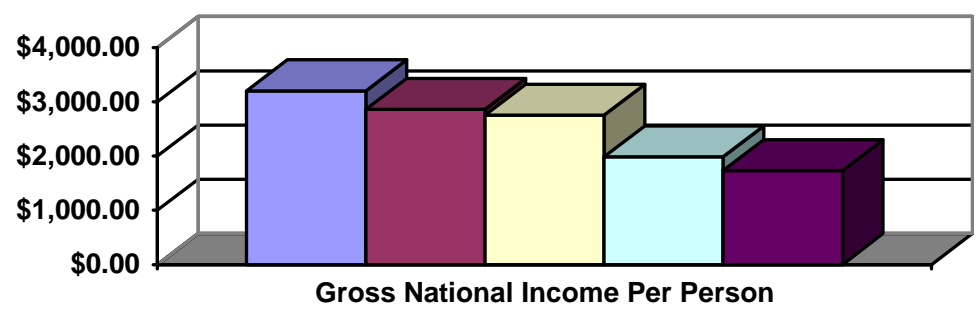

पBotswana: $\square$ Gabon: $\square$ South Africa: $\square$ Tunisia: $\square$ Namibia:

Figure 4. Graph of gross national income per person: Top Five African nations as of year end 2010 [46].

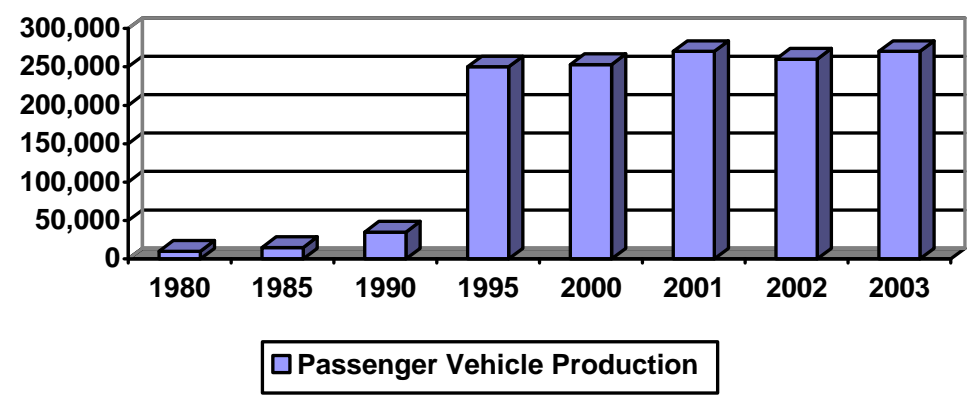

Figure 5. Passenger vehicle production in South Africa [35]. 
By taking advantage of recent developments in best industry practices and state-of-the-art technologies, South Africa could increase adoption rates of hybrids and electric vehicles in the short term. Based on South Africa's experiences, the other developing countries of Africa could implement their own fine-tuned versions based on local needs and preferences. Clearly, this is a fluid situation and any number of factors could affect the outcomes of investments in a specific technology today [36] as well as how measures such as "fuel economy" should be defined, and even the best models are qualified by these fundamental limitations [37]. Therefore, identifying the most appropriate direction for private-public sector investments in alternative energy for passenger vehicles and mass transit applications represents an important and timely enterprise for these developing countries as well as emerging economic powerhouses such as China that have established ambitious GHG reduction goals [35].

\subsection{Cost, Prices and Affordability Especially of The latest Models Incorporating Efficiency and Environmental Improvement Strategies}

Of the 200 million vehicles on the road at present, about 133 million are passenger vehicles but just 300,000 of these are hybrids of some type, defined as vehicles that run on more than one source of power [38]. Although configurations vary, the majority of hybrids currently operate using a combination of rechargeable batteries and conventional gasoline [38]. Factors that will need to be taken into account in determining whether the latest models provide the requisite savings in cost and reductions in toxic emissions to justify their investment include:

1).Fuel, purchase price, and tax incentives are important factors to consider; however, other savings and expenses can be difficult to estimate.

2).Insurance costs are generally lower for hybrids.

3).Battery replacement and electricity usage expenses can tip the scale the other way; the hybrid battery packs generally last 150,000 to 200,000 miles.

4).Using the 15,000-mile-a-year average of the American consumer, traditional Honda Civics costs about $\$ 17,110$, and it gets about 30 miles per gallon in the city and 40 highway. At $\$ 2.92$ a gallon, this subcompact car costs $\$ 1,296$ in gasoline in one year. At $\$ 22,900$, the Honda Civic Hybrid will initially cost a bit more, but with an average of 50 miles per gallon, a year of gas will cost $\$ 878$. In 10 years, taking into account inflation at 3 percent but not factoring in any possible changes in gas prices, the gas savings of a hybrid reaches almost $\$ 5,000$ [38].
5).After 10 years, the operation of a hybrid will ultimately save about $\$ 1,229$ [38].

Affordability can be regarded as the price of an item as a percentage of monthly personal disposable income. Price affordability of vehicles in African nations will inherently depend on several factors such as per capita income, inflation, strength or purchasing power of local currency, country size, societal and cultural factors and infrastructure, to name a few. With such vehicles incorporating advanced alternate energy technologies that improve the environment, affordability becomes even more difficult for the bulk of the African continent. Efforts to combat poverty and create jobs which could also be done through investments and adoption of alternative energy technologies must be doubled, as must the necessary road infrastructures and networks be expanded to increase affordability of cleaner and less polluting vehicles on the continent.

\subsection{Possible Future Development Paths for the Continent}

Many developing nations appear to be well situated to take advantage of hybrid technologies in expanding their national fleets of passenger vehicles. At the national, regional and local governmental levels, hybrids and CNG-powered vehicles could be used for large light service vehicle fleets (this approach is already being used by the U.S. Postal Service as noted above) or for commercial applications (as with United Parcel Service and Pepsi-Cola). The investments in such initiatives stand to provide a significant return on investment as

also noted above, and current trends indicate that adoption rates for these alternative technologies will increase in the near term. A study by [39] analyzed hybrid and CNG-powered vehicle adoption rates in the European Union according to several potential scenarios, including an "alternative technologies emerge" approach that projected a mix of alternative powertrains (e.g. gasoline turbo, hybrids and

CNG) of 55 percent of total sales by 2035. Projected adoption rates of gasoline- and diesel-hybrids and CNG-powered light service vehicles for the EU are depicted in Figure 6.

While Bodeck et al. [39] remark that the scenario may appear grim in terms of the adoption of renewable energy technologies, it is however important to note that both diesel hybrids and gasoline hybrids have components of renewable energy from the biofuel side that could result into a net positive effect on the environment. In fact, as can be readily discerned from the projections for hybrids and CNG-powered vehicles through 2035 in Figure 5 above, the respective market share of such vehicles in the 


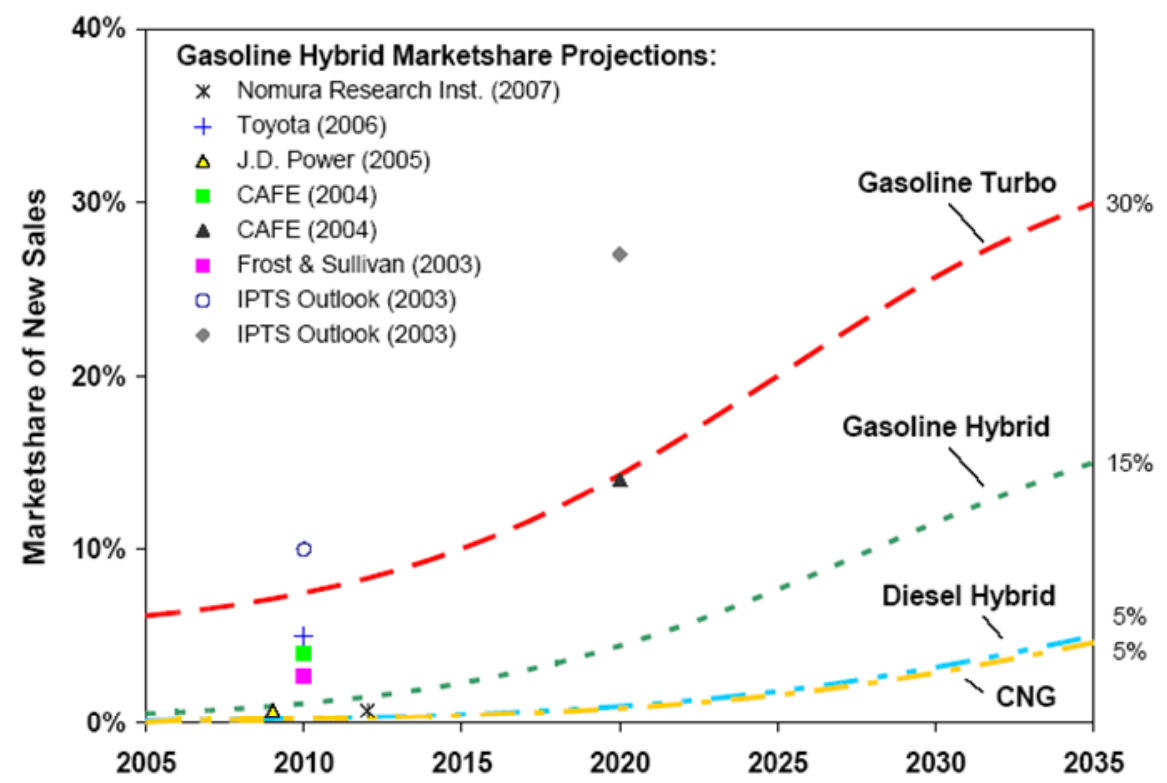

Figure 6. Projected adoption rates of hybrid and CNG technologies in the EU 2005-2035 [39].

EU and their adoption rates are modest making the need for urban mass transit additions to the mix vitally important, and these issues are discussed further. The gasoline hybrid market share projections indicates studies that have been performed by several research groups such as Nomura Research Institute, Frost and Sullivan and so on, showing market share growth of these alternative technologies.

(a) Urban Mass Transit Focus. As noted above, a number of major operators, including United Parcel Service, Pepsi-Cola and the U.S. Postal Service already used compressed natural gas to fuel to their massive fleets and the use of alternative fuel vehicles for urban mass transit has become the focus of an increasing amount of attention in recent years. The existing urban mass transit systems that are in place in developing countries such as Botswana et al. are certainly suitable for adding hybrid and electric vehicles to their to existing fleets and replacing outdated vehicles with these alternatives whenever possible [40], with available resources being the overriding constraint to any such initiative. To buttress further, most developing countries desperately need these cleaner solutions for their mass transit systems to help reverse the enormous amounts of toxic emissions that are currently being generated by aging and inefficient gasoline-powered mass transit systems [41].

(b) The UAE (United Arab Emirates) Renewable Energy Based City Model. This is an ambitious project sponsored by the UAE government that will span decades in an effort to "transform oil wealth into re- newable energy leadership" [42]. The three-phase project is designed to create the world's first city that is truly renewable-energy powered in a highly integrated fashion, including the provision of the infrastructure needed for renewable-energy powered passenger vehicles [43]. The successes and failures of this bold project will provide some useful best practices for other countries as they seek the most effective renewable energy alternative for their own unique needs.

\section{Impact on the Developing Country of China}

With respect to the Chinese automobile industry, this is currently the largest and fastest growing automobile market in the world, the impact economically, environmentally and politically will continue to be profound. According to a 2001 report by the World Bank, Beijing and Shanghai lead the way in air pollution amongst mega cities of the world. An increase in China's living standards and quality of life has led to a significant surge in demand for quality automobiles and this growth is expected to continue for the foreseeable future. This growth has led to structural changes in China [47]. Government policy and regulatory instruments to promote economic development through the automobile sector has been one of the main driving forces behind the continued global increase in demand for oil and increase in market price of oil. This is invariably detrimental for the environment in terms of GHG emissions. The Chinese environment 
will suffer from increased pollution to urban cities and surroundings. This has however led the Chinese government to make climate impacts as part of its policy agenda [48]. There is an ongoing push to begin to shift to production and use of more energy and environmentally friendly vehicles. Efforts are also been made to reduce and replace oil imports with domestic natural gas reserves. Where barriers exist, so do opportunities for improvement. Climate change mitigation efforts need to be accelerated. Domestic capacity for technological innovation, development and advancement for urban transportation, a robust transportation infrastructure, carbon capture and storage need to also be a top government and private sector priority. Market and consumer incentives that heavily favor use of alternative fuel vehicles and fuel refiners should be promoted. As a still developing country, China will be able to draw on past experiences of industrialized nations and will be well positioned to equally benefit from new and future automobile technological innovations.

\section{Conclusions}

The review work showed that a number of alternative energy sources are being actively promoted as potential replacements for current gasoline- and diesel-powered engines. Among the more promising of these potential alternatives were natural gas and fuel cells based on their proven track records of performance and cost effectiveness. These and other emerging technologies, though, will require an enormous investment in infrastructure in order to support their widespread deployment.

One of the harsh realities of life in the $21^{\text {st }}$ century is the inextricable relationship between modern life and petroleum products. Virtually every area of human life is touched in major ways by petrochemicals, and humanity has come to rely on fossil-fuel based technologies for their livelihoods and ways of life. Breaking this powerful bond will require time, of course, but the handwriting is on the wall for all to see and the day will come-sooner or later - when the last drop of oil is extracted from the earth and the natural processes that required tens of millions of years to create it will not replenish it soon enough. Taken together, these trends demand that steps are taken today to ensure that viable alternative energy sources are developed and deployed in ways that will avoid a collapse of the global economy with the devastation this would cause. A drastic problem often requires a drastic solution, therefore, further efforts into research in all alternative energy resources needs to drastically increase, with a special focus on natural gas and biofuel technologies for the short term and solar-power, hydrogen and fuel cell technologies for the long term, to help ensure that the passenger vehicle industry can continue to provide the essential transportation services needed by an increasing number of consumers in the 21 st century and beyond.

\section{References}

[1] Derry, T. K. and T. I. Williams, "A Short History of Technology from the Earliest Times to A.D. 1900," Oxford University Press, New York, 1961.

[2] L. Dixon, I. Porche and J. Kulick, "Driving Emissions to Zero: Are the Benefits of California's Zero Emission Vehicle Program Worth the Costs?" Rand Science and Technology, 2002.

[3] J. B. Skjaerseth and T. Skodvin, "Climate Change and the Oil Industry: Common Problem, Varying Strategies," Manchester University Press, Manchester, England, 2003.

[4] J. A. Fay and D. S. Golomb, "Energy and the Environment," Oxford University Press, New York, 2002.

[5] L. Day and I. Mcneil, "Biographical Dictionary of the History of Technology," Routledge, London, 1998.

[6] T. Klier and J. Rubenstein, "Who Really Made Your Car? Restructuring and Geographic Change in the Auto Industry," W.E. Upjohn Institute for Employment Research, Kalamazoo, MI, 2008.

[7] Mazda RX7 Association, "How a Rotary Engine Works," 2011. http://mazda-rx7.org/

[8] R. W. Lowne, "The Effect of Road Surface Texture on Tyre," Wear, Vol. 15, No. 1, 1970, pp. 57-70. doi:10.1016/0043-1648(70)90186-9

[9] "Tires and Passenger Vehicle Fuel Economy: Informing Consumers, Improving Performance," Transportation Research Board Washington, DC, 2006.

[10] C. Evans, L. Cheah, A. Bandivadekar and J. Heywood, "Getting More Miles per Gallon; the Answer May Require Looking beyond CAFE Standards and Implementing Other Consumer-Oriented Policy Options to Wean Drivers Away from Past Habits," Issues in Science and Technology, Vol. 25, No. 2, Winter 2009, pp. 71-73.

[11] J. Thewlis, R. C. Glass, D. J. Hughes and A. R. Meetham, "Encyclopedic Dictionary of Physics: General, Nuclear, Solid State, Molecular, Chemical, Metal and Vacuum Physics, Astronomy, Geophysics, Biophysics, and Related Subjects," Pergamon Press, New York, 1971.

[12] C. F. Tweney and L. E. Hughes, "Chambers's Technical Dictionary," Macmillan, New York, 1958.

[13] M. Koike, T. Nagayoshi and N. Hamamoto, "Research on Aerodynamic Drag Reduction by Vortex Generators," Mitsubishi Motors Technical Review, No. 16, 2004, pp. 11-16.

[14] S. F. Hoerner, "Fluid-Dynamic Drag," Published by Author, 1958.

[15] N. T. Boaz, "Eco Homo: How the Human Being Emerged from the Cataclysmic History of the Earth," Basic Books, New York, 1997. 
[16] T. E. Kraft "The Electric Vehicle Experience," Journal of Technology Studies, Vol. 28, No. 1/2, 2002, pp. 150-152.

[17] H. Zervos, "Solar Power for Electric Vehicles," 2010. http://www.interpv.net/market/market_view.asp?idx=342 \&part_code $=01 \&$ page $=1$

[18] C. Bomb, K. McCormick, E. Deurwaarder and T. Kaberger, "Biofuels for Transport in Europe:Lessons from Germany and UK," Energy Policy, Vol. 35, No. 4, 2007, pp.2256-2267. doi:10.1016/j.enpol.2006.07.008

[19] D. Hayes, B. Babcock, J. Fabiosa, S. Tokgoz, A. Elobeid, T. Yu, et al., "Biofuels: Potential Production Capacity, Effects on Grain and Livestock Sectors, and Implications for Food Prices and Consumers," Journal of Agricultural and Applied Economics, Vol. 41, No. 2, 2009, pp. 465-491.

[20] R. Hoogma, R. Kemp, J. Schot and B. Truffer, "Experimenting for Sustainable Transport: The Approach of Strategic Niche Management," Spon Press, New York, 2002.

[21] Scientific American, "Electric Cars-How Much Does It Cost per Charge?" 2009.

http://www.scientificamerican.com/article.cfm?id=electri c-cars-cost-per-charge.

[22] G. Alckmin and J. Goldemberg, "Assessment of Greenhouse Gas Emissions in the Production and Use of Fuel Ethanol in Brazil," 2004. http://www.unica.com.br/

[23] L. Lauerman, "Science \& Technology Almanac," Greenwood Press, Westport, CT, 2002.

[24] B. D. Yacobucci, "Natural Gas Passenger Vehicles: Availability, Cost and Performance," Congressional Research Service Washington, DC, 7-5700, 2010.

[25] J. A. Gomez-Ibanez, W. B. Tye and C. Winston, "Essays in Transportation Economics and Policy: A Handbook in Honor of John R. Meyer," Brookings Institute Washington D.C., 1999.

[26] C. J. Winter, "Hydrogen Energy-Abundant, Efficient, Clean: A Debate Over Energy-System-Of-Change," International Journal of Hydrogen Energy, Vol. 34, No. 14, 2009, S1-S52.

[27] D. S. Scott, "Smelling Land, the Hydrogen Defense Against Climate Catastrophe," 2006. http://www.H2.ca

[28] A. Friedemann, "The Hydrogen Economy," Skeptic, Vol. 14, No. 1, 2008, pp. 48-51.

[29] "Breaking the Tether of Fuel," Military Review, Vol. 87, No. 1, 2007, pp. 96-97.

[30] E. Karden, P. Shinn, P. Bostock, J. Cunningham, E. Schoultz and D. Kok, "Requirements for the Future Automotive Batteries-snapshot," Journal of Power Sources, Vol. 144, No. 2, 2005, pp. 505-512. doi:10.1016/j.jpowsour.2004.11.007

[31] M. J. Kellaway, "The Automotive Battery of the Future-The Role of Electronics," Journal of Power Sources, Vol. 144, No. 2, 2005, pp. 467-472. doi:10.1016/j.jpowsour.2004.10.033
[32] P. Jackson and R. Suomi, "Ebusiness and Workplace Redesign," Routledge, 2001.

[33] G. M. J. Boko, M. J. Bunch, V. M. Suresh and T. V. Kumaran, "Air Pollution and Respiratory Diseases in African Big Cities: The Case of Cotonou in Benin," Proceedings of the Third International Conference on Environmental and Health, Chennai, India, 2003, pp. 32-43.

[34] J. Larmine, "Fuel Cell Systems Explained," John Wiley \& Sons, $2^{\text {nd }}$ Edition, 2003.

[35] M. Holweg, J. Luo and N. Oliver, "The Past, Present and Future of China's Automotive Industry," Paper in preparation for submission to UNIDO's Global Value Chain Project.

[36] A. Lovins, "Reinventing the Wheels," Environmental Health Perspectives, Vol. 113, No. 4, 2005, pp. 218-220. doi:10.1289/ehp.113-a218

[37] R. B. Ludwiszewski and H. C. Haake, "Cars, Carbon and Climate Change," Northwestern University Law Review, Vol. 102, No. 2, 2008, pp. 665-694.

[38] S. Goudarzi, "Hybrid Cars: How They Work and What They Really Cost," 2011. http://www.livescience.com/758-hybrid-cars-work-cost.ht $\mathrm{ml}$.

[39] K. Bodeck and J. Heywood, "Europe's Evolving Passenger Vehicle Fleet:Fuel Use and GHG Emissions Scenarios through 2035," Laboratory for Energy and Environment-Massachusetts Institute of Technology Publication, No. LFEE 2008-03 RP.

[40] S. Hansen and G. Giuliano, "The Geography of Urban Transportation," Guilford Press, New York, 2004.

[41] S. Alipour, A. R. Karbassi, M. Abbaspour, M. Saffarzadeh and N. Moharamnejad, "Energy and Environmental Issues in Transport Sector," International Journal of Environmental Research, Vol. 5, No. 1, 2011, pp. 213-224.

[42] D. Reiche, "Renewable Energy Policies in the Gulf Countries: A Case Study of the Carbon-Neutral 'Masdar City' in Abu Dhabi," Energy Policy, Article in Press.

[43] "Masdar City Project Development Overview," MIT/The Masdar Institute, 2009.

[44] http://www.turbos.bwauto.com/images/products/schemati cPistonEngine.gif

[45] http://4.bp.blogspot.com/_sCnekBnBzr4/SMO9b7MjAeI/ AAAAAAAAADE/uOuŌ $1 w S$ 2DmE/s400/wankel+engine.gif

[46] http://www.nationmaster.com/graph/eco_gro_nat_inc_per cap-gross-national-income-per-capita

[47] E. Hirabayashi, "The Chinese Automobile Indsutry," Stanford University Press, Stanford, 1997.

[48] L. Gan, "Globalization of the Automobile Industry in China: Dynamics and Barriers in Greening of the Road Transportation," Energy Policy, Vol. 31, No. 6, 2003, pp. 537-551. doi:10.1016/S0301-4215(02)00097-6 


\section{Appendix}

\begin{tabular}{|c|c|c|c|}
\hline \multicolumn{3}{|c|}{ Nomenclature/Acronyms } \\
\hline ICE & internal combustion engine & NGV & natural gas vehicles \\
\hline HEV & hybrid electric vehicle & HV & hybrid vehicles \\
\hline ICV & internal combustion vehicle & BEV & battery electric vehicles \\
\hline FC & fuel cell & EV & electric vehicles \\
\hline FCEV & fuel cell electric vehicle & FCV & fuel cell vehicle \\
\hline SI & spark ignition & TPMS & tire pressure monitoring system \\
\hline PHEV & plug-in hybrid electric vehicle & GHG & green house gases \\
\hline CNG & compressed natural gas & CNGV & compressed natural gas vehicle \\
\hline LNG & liquefied natural gas & OEM & original equipment manufacturer \\
\hline MY & model year & EPRI & electric power research insitute \\
\hline EU & european union & UAE & united arab emirates \\
\hline OPEC & organisation of petroleum exporting countries & SPV & solar photovoltaic vehicle \\
\hline LNGV & liquefied natural gas vehicles & R\&D & research and development \\
\hline
\end{tabular}

